\title{
Clinical Implication of Surgically treated Abdomino- perineal Soild Tumor in the Newborn : A Single-Center Experience
}

Yong-Hoon Cho, Soo-Hong Kim, Hae-Young Kim, Young-Mi Han*, Na-Rae Lee*, Mi-Hye Bae*, Kyung-Hee Park*, and Shin-Yun Byun*

Division of Pediatric Surgery, Department of Surgery, Pusan National University School of Medicine, Yangsan, Korea Division of Neonatology*, Department of Pediatrics, Pusan National University School of Medicine, Yangsan, Korea

\section{ABSTRACT}

Purpose: Abdominoperineal solid tumors presenting in neonates often require surgical intervention during the neonatal period. Although we report our single-center experience, this study would be meaningful to understand the clinical implications of these neoplasms.

Methods: We retrospectively reviewed and analyzed the clinical data and characteristics of 22 patients ( $\leq 28$ days old) diagnosed with histopathologically confirmed abdominoperineal solid neoplasms (benign or malignant) after surgical resection.

Results: The mean gestational age and postnatal age at the time of operation were $38.3 \pm 1.8$ weeks and $13.5 \pm 8.3$ days, respectively. Most patients $(18 / 22,81.8 \%)$ were diagnosed during antenatal care visits; however, 4 (18.2\%) were identified after birth. The mean tumor size was $6.4 \times 5.3 \mathrm{~cm}(3.5-17.0 \mathrm{~cm})$, and tumors occurred most frequently within the sacrococcygeal region (8/22, 36.4\%). Histopathologically, 14 patients $(63.6 \%)$ demonstrated benign tumors and $8(36.4 \%)$ demonstrated malignant tumors. Germ cell tumors and hepatoblastomas were the most commonly observed tumors. Fortunately, all patients showed a localized pattern of tumor involvement without distant metastasis. No recurrence or mortality was observed during the follow-up period (mean 66.4 \pm 44.2 months).

Conclusion: Abdominoperineal solid tumors occurring in neonates show variable clinical patterns during the antenatal and postnatal monitoring/screening periods. We conclude that aggressive and multidisciplinary approaches could achieve good clinical results in these patients.

Key Words: Abdominoperineal, Solid tumor, Newborn

서론

신생아기 종양은 전체 소아청소년기 종양의 $2 \%$ 정도를 차지하며, 정상 출생아 $12,500-27,500$
Received: 11 September 2017

Revised: 9 December 2017

Accepted: 27 December 2017

Correspondence to: Young-Mi Han

Department of Pediatrics, Pusan

National University School of

Medicine, 20 Geumo-ro, Yangsan

50612, Korea

Tel: + 82-55-360-2180

Fax: +82-55-360-2181

E-mail: skybluehym@gmail.com

Copyright(c)

By Korean Society of Neonatology.

All right reserved.

This is an Open-Access article distributed under the terms of the Creative Commons Attribution Non-Commercial License (http://creativecommons.org/licenses/ by-nc/4.0), which permits unrestricted non-commercial use, distribution, and reproduction in any medium, provided the original work is properly cited. 
명당 1 명 정도에서 발생하는 것으로 추정된다 ${ }^{1,2)}$. 이들의 약 $75 \%$ 에 서 고형 종양의 형태를 보이며 대부분은 양성 종양의 임상 양상을 보 이지만, 일부에서는 악성의 임상경과를 보여 주산기 사망률에 영향 을 준다 ${ }^{1,3-5)}$. 최근 신생아기 종양이 증가한다는 보고도 있었으나 ${ }^{(0)}$ 실 제 발병의 증가라기 보다 산전검사 빈도의 증가와 영상 검사법의 진 보로 인한 것일 수 있다. 그러나 사산, 유산 또는 보고되지 않은 증례 를 감안한다면 실제 유병률은 더 높겠다.

종양 발생학적 관점에서 성인 종양은 외부환경에 대한 인체의 반 응이 큰 원인을 차지하지만, 신생아기 종양은 태생기 종양(embryonic tumor)의 일종으로 신생물인 동시에 조직 형성과정 중에 일어나 는 선천적 기형이다,7). 따라서 발생 빈도 및 부위, 병리조직학적 특 성, 임상 양상 및 치료에 있어 이후에 발생하는 소아 종양과는 다른 양상을 보인다.

본 기관은 소아외과 진료를 요하는 신생아의 분만 및 전원이 비교 적 많은 병원으로, 복부 및 회음부의 고형종양이 의심되는 신생아 에 대한 검사와 치료가 이루어지고 있다. 이에 후향적 연구로 15 년
간 단일기관 신생아집중치료실에서 치료 경험한 신생아기 종양 중 병리조직학적으로 최종 확진 된 복부 및 회음부에 발생한 고형 종양 을 대상으로 진단 및 치료 과정, 임상 경과에 대해 분석하고 특징을 살펴보았다. 저자들이 아는 한 신생아의 복부 및 회음부의 전반적인 고형종양에 대한 국내 보고가 부재한 상황으로, 본 연구를 통해 산전 또는 출생 후 복부 및 회음부 종양이 발견되었을 때 고려할 질환과 그 경과에 대한 참고자료가 되어 산과와 신생아의 진료에 도움이 되 고자 한다.

\section{대상 및 방법}

\section{1. 대상}

2002년 1월부터 2016년 12월까지 단일기관 신생아집중치료실에 입원한 신생아 중 수술 후 최종 병리조직검사 결과에서 종양으로 확 진 된 환자는 23명이었다. 그 중 발생 부위가 목이었던 1명을 제외하

Table 1. Clinical Characteristics

\begin{tabular}{|c|c|c|c|c|c|c|c|c|c|c|c|c|}
\hline No & Year & $\begin{array}{c}\text { GA } \\
\text { (wks) }\end{array}$ & $\begin{array}{l}\text { Birth } \\
\text { weight } \\
\text { (g) }\end{array}$ & Sex & Delivery & $\begin{array}{l}\text { Apgar } \\
\text { score } \\
(1 / 5)\end{array}$ & $\begin{array}{c}\text { Detected wks } \\
\text { at ANC } \\
\text { (postnatal sign)* }\end{array}$ & $\begin{array}{l}\text { Age } \\
\text { at op. } \\
\text { (d) }\end{array}$ & Location & Pathology & $\begin{array}{c}\text { Mass size } \\
(\mathrm{cm})\end{array}$ & CTx. \\
\hline 1 & 2002 & $37^{+3}$ & 3,600 & M & C-sec & - & Yes, but unknown & 23 & Liver & Infantile hemangioendothelioma & $6 \times 5$ & - \\
\hline 2 & 2003 & $41^{+1}$ & 3,400 & $\mathrm{~F}$ & C-sec & $8 / 9$ & Yes, but unknown & 8 & SC & Mature teratoma & $4.4 \times 2.3 \times 1.5$ & - \\
\hline 3 & 2004 & $36^{+1}$ & 3,612 & M & C-sec & - & 20 & 8 & SC & Immature teratoma & 10 & - \\
\hline 4 & 2004 & $39^{+0}$ & 2,800 & $\mathrm{~F}$ & NSVD & - & Yes, but unknown & 17 & SC & Mature teratoma & $9 \times 5.4$ & - \\
\hline 6 & 2004 & $39^{+6}$ & 3,940 & M & NSVD & - & Yes, but unknown & 29 & Liver & Epithelial hepatoblastoma, fetal & $3.7 \times 2.5$ & 6 th \\
\hline 7 & 2006 & $41^{+0}$ & 3,850 & $\mathrm{~F}$ & NSVD & $7 / 9$ & 39 & 9 & Lt. adrenal & Neuroblastoma, undifferentiated & $5 \times 5 \times 3.5$ & - \\
\hline 8 & 2009 & $40^{+3}$ & 3,020 & $\mathrm{~F}$ & NSVD & $9 / 10$ & 39 & 15 & Lt. adrenal & Neuroblastoma, differentiated & $6 \times 4.3$ & \\
\hline 9 & 2010 & $38^{+0}$ & 3,230 & M & C-sec & $7 / 8$ & 32 & 14 & SC & Mature teratoma & 5 & - \\
\hline 10 & 2010 & $35^{+4}$ & 3,400 & M & C-sec & $8 / 9$ & 35 & 14 & $\mathrm{RP}$ & Mature teratoma & $5.2 \times 4.5$ & - \\
\hline 14 & 2012 & $37^{+6}$ & 3,500 & $\mathrm{~F}$ & C-sec & $7 / 8$ & 34 & 7 & Rt. ovary & Teratoma & $6.1 \times 4$ & - \\
\hline 15 & 2013 & $37^{+3}$ & 4,400 & $\mathrm{~F}$ & C-sec & $8 / 9$ & (Hemihypertrophy) & 19 & Liver & Epithelial hepatoblastoma, mixed & $7.6 \times 5.5$ & 4 th \\
\hline 16 & 2014 & $38^{+4}$ & 2,840 & M & C-sec & - & (Abd. distention) & 29 & Rt. adrenal & Mature teratoma & $4.5 \times 5$ & - \\
\hline 17 & 2014 & $41^{+1}$ & 3,400 & $\mathrm{~F}$ & NSVD & $7 / 8$ & 29 & 7 & Lt. ovary & Teratoma & 4 & - \\
\hline 18 & 2016 & $40^{+1}$ & 3,400 & $\mathrm{~F}$ & NSVD & $5 / 7$ & 32 & 9 & Rt. ovary & Teratoma & 3.5 & - \\
\hline 19 & 2016 & $36^{+4}$ & 3,960 & M & C-sec & $4 / 6$ & 35 & 1 & $\mathrm{RP}$ & Mature teratoma & $9.3 \times 1.9 \times 0.3$ & - \\
\hline 20 & 2017 & $40^{+0}$ & 3,330 & $\mathrm{~F}$ & C-sec & $8 / 9$ & 20 & 7 & SC & Mature teratoma & $5 \times 3$ & - \\
\hline 21 & 2017 & $38^{+4}$ & 3,140 & $\mathrm{~F}$ & C-sec & - & (Cystic mass) & 15 & SC & Mature teratoma & $3.1 \times 1.8$ & \\
\hline 22 & 2017 & $38^{+6}$ & 3,610 & M & NSVD & $8 / 9$ & 38 & 20 & Liver & Epithelial hepatoblastoma, mixed & 3.8 & 4 th \\
\hline
\end{tabular}

(postnatal sign)* means chief complaints of newborn who was not detected at antenatal clinic.

No.15 patient was diagnosed with Beckwith-Widemann syndrome and No.16 patient had intestinal malrotation without volvulus.

Abbreviations: M, male; F, female; C-sec, cesarean section; NSVD, normal spontaneous vaginal delivery; GA, gestational age; ANC, antenatal clinic; op, operation; CTx, chemotherapy; SC, sacrococcyx; RP, retroperitonium; S-colon, sigmoid colon. 
고 복강 및 회음부에 발생한 고형종양 환자 22 명을 대상으로 연구하 였다.

\section{2. 방법}

대상 환자의 의무 기록을 통해 재태 주수, 출생 시 체중, 성별, 분 만 방법, 산전 선별검사 확인 여부 및 진단시기, 수술 당시 연령, 종 양의 발생 부위와 크기 및 조직검사결과, 수술 후 보조치료 시행 여 부에 대하여 후향적으로 분석하였다.

\section{결과}

\section{1. 기초 임상 정보}

대상아 22 명의 평균 재태 기간은 $38.3 \pm 1.8$ 주(35-41주), 평균 출생

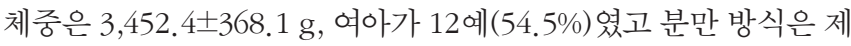
왕절개가 13 예(59.1\%)였다. 산전 선별검사 중 확인 된 경우가 18 예 (81.8\%)이었고 수술 당시 출생 후 연령은 평균 13.5 \pm 8.3 일(1-29일) 이었다(Tables 1,2).

\section{2. 임상 특징}

종물에 대한 검사 및 치료를 결정하게 된 주 호소로는 산전 선별검 사에서 발견된 복강 내 덩이가 18예(81.8\%)로 대부분이었고 첫 진단 된 임신 주수는 20 주에서 39주로 다양하였으나 4예에서는 알 수 없 었다. 산전 이상을 발견하지 못하고 출생한 경우는 4예로 산전 태아 의 복수가 있었던 1 예, 출생 후 복부팽만 1 예, 생후 17 일에 왼쪽 반신 비대와 큰 혀가 관찰된 1 예, 그리고 꼬리뼈 부위에 $4 \mathrm{~cm}$ 의 낭성 덩이 가 관찰된 1 예였다.

부위는 엉치꼬리가 8예(36.4\%)로 가장 많았고, 그 외 간 4예(18.3 $\%$, 난소, 부신, 배막뒤공간이 각 3예(13.6\%), 구불잘록창자 1예(4.5 $\%$ )로 확인되었다. 종양의 크기는 평균 $6.4 \times 5.3 \mathrm{~cm}$ (최소 $3.5 \mathrm{~cm}$, 최 대 $17.0 \mathrm{~cm}$ ) 였다. 모든 간모세포종, 신경모세포종, 섬유육종 환자 에서는 컴퓨터단층촬영술(computed tomography, CT), 자기공명 영상(magnetic resonance imaging, MRI) 및 양전자방출단층촬영

Table 2. Demographic Findings

\begin{tabular}{lc}
\hline & $\mathrm{n}=22$ \\
\hline Male, $\mathrm{n}(\%)$ & $10(45.5)$ \\
Gestational age (wks) & $38.3 \pm 1.8(35-41)$ \\
Birth weight (g) & $3,452.4 \pm 368.1$ \\
Cesarean section, $\mathrm{n}(\%)$ & $13(59.1)$ \\
Postnatal age at operation (d) & $13.5 \pm 8.3(1-29)$ \\
Detection during ANC (\%) & $18(81.8)$ \\
\hline
\end{tabular}

Values are mean $\pm \mathrm{SD}$ (range).

Abbreviation: ANC, antenatal clinic. (positron emission tomography-computerized tomography, PETCT) 검사를 시행하였고, 최종 임상 병기는 모든 경우에서 원격전이 없이 발생부위에 국한되어 있었다(Tables 1,3 ).

\section{3. 병리조직학적 결과 및 보조 화학 요법}

병리조직검사 결과는 양성 14예(63.6\%)와 악성 8예(36.4\%)였으 며, 배아세포종양이 15 예(68.2\%)로 가장 많은 빈도를 보였다. 양성 종양은 배아세포종양 13예(92.9\%) 및 영아 간 혈관내피종 1예(7.1 $\%)$ 였고, 악성종양은 상피 간모세포종 3 예(37.5\%), 배아세포종양 및 신경모세포종 각 2 예(9.2\%), 영아섬유육종 1예(12.5\%)였다(Tables $1,4)$.

모든 종양에서 완전한 외과적 절제가 시행되었고, 3 예의 상피 간 모세포종에서 수술 후 보조 화학요법을 시행하였다. 영아섬유육종 1 예는 수술 절제부위가 깨끗하였으며 잔존 종양이 없어 보조 항암치

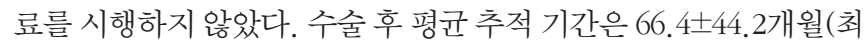
소 7 개월-최대 120 개월)로 수술 전후 전체 추적 기간 동안 종양 및 수 술과 관련되어 발생한 뇌신경학적 결함이나 배변과 배뇨장애는 발 생하지 않았고 재발과 사망도 없었다.

\section{고찰}

신생아기 종양 자체는 매우 드물며, 이 중 고형종양이 가장 흔한 형태로 전체 신생아 종양의 $75 \%$ 이상을 차지하지만 정확한 발병 빈

Table 3. Summary of Clinical Characteristics

\begin{tabular}{lc}
\hline & $\mathrm{n}=22$ \\
\hline Main sign and symptom, $\mathrm{n}(\%)$ & $18(81.8)$ \\
Antenatal mass & $1(4.5)$ \\
Abdominal distention & $1(4.5)$ \\
Antenatal ascites & $1(4.5)$ \\
Hemihypertrophy & $1(4.5)$ \\
Cystic mass & \\
Anatomical location, $\mathrm{n}(\%)$ & $8(36.4)$ \\
Sacrococcyx & $4(18.3)$ \\
Liver & $3(13.6)$ \\
Ovary & $3(13.6)$ \\
Adrenal gland & $3(13.6)$ \\
Retroperitoneum & $1(4.5)$ \\
Other (Sigmoid colon) & $6.4 \times 5.3(3.5-17.0)$ \\
Mass size, mean (cm) & \\
Associated anomaly, $\mathrm{n}(\%)$ & $1(4.5)$ \\
Beckwith-Widemann syndrome & $1(4.5)$ \\
Malrotation & $22(100)$ \\
Localized mass, $\mathrm{n}(\%)$ &
\end{tabular}


Table 4. Anatomical location and Pathology

\begin{tabular}{lll}
\hline \multirow{2}{*}{ Anatomical location } & \multicolumn{1}{c}{ Benign, $\mathrm{n}=14(63.6 \%)$} & Pathology \\
\cline { 2 - 3 } Liver $(\mathrm{n}=4)$ & Infantile hepatic hemangioendothelioma $(\mathrm{n}=1)$ & Malignancy, $\mathrm{n}=8$ (36.4\%) \\
& & $\begin{array}{l}\text { Epitherial hepatoblastoma, fetal }(\mathrm{n}=1) \\
\text { Epitherial hepatoblastoma, mixed }(\mathrm{n}=2)\end{array}$ \\
Ovary $(\mathrm{n}=3)$ & Mature teratoma $(\mathrm{n}=3)$ & - \\
Sacrococcyx $(\mathrm{n}=8)$ & Mature teratoma $(\mathrm{n}=7)$ & Immature teratoma $(\mathrm{n}=1)$ \\
Adrenal gland $(\mathrm{n}=3)$ & Mature teratoma $(\mathrm{n}=1)$ & Neuroblastoma, differentiated $(\mathrm{n}=1)$ \\
& & Neuroblastoma, undifferentiated $(\mathrm{n}=1)$ \\
Retroperitoneum $(\mathrm{n}=3)$ & Mature teratoma $(\mathrm{n}=2)$ & Immature teratoma $(\mathrm{n}=1)$ \\
Sigmoid colon $(\mathrm{n}=1)$ & - & Infantile fibrosarcoma $(\mathrm{n}=1)$
\end{tabular}

도나 경과에 대해서는 잘 알려져 있지 않다 ${ }^{1,3-5)}$. 종양에 따른 산전 선 별검사에서의 확인 비율은 정확히 알려지지 않았지만 많은 경우 산 전 선별검사에서 발견되며, 이는 검사의 빈도 증가 및 장비 개선의 영향이 큰 것으로 보인다. 성별 분포에 있어서 배아세포종양을 제외 하고는 남녀 비율이 거의 대등하다고 알려져 있고, 일부 연구에서는 재태 연령 및 저체중 출생과 종양발생의 연관성을 제기하고 있지만 명확한 결론은 없다 ${ }^{8-10)}$. 본 연구에서는 출생 전 발견 비율이 $81.8 \%$ 였고, 남녀 성비가 1:1.2로 큰 차이가 없었으며 평균 재태 연령은 $38.3 \pm 1.8$ 주, 미숙아는 4예(18.2\%)로 적었다. 본 연구에서 시간 경과 에 따른 뚜렷한 증감은 확인할 수 없었다. 전수 조사가 아닌 한 기관 의 자료이며, 해마다 전체 출생에 대한 비율을 본 것이 아니기에 본 자료만으로 증감을 추정할 수 없었다. 다만 산전 검사의 증가 및 장 비의 개선 등으로 산전에 발견되는 이상이 많은 만큼 분만으로 이어 지지 못하는 경우도 있을 수 있겠다.

신생아기 종양의 발생과 관련된 요인으로 염색체 이상과 같은 유전적 요인과 출생 전-후 방사선 피폭, 모체의 약물 복용, 감염 등 이 있으며 ${ }^{11-16)}$, 특히 다른 선천성 기형과 연관되어 발생하는 신생 아기 종양이 $15-20 \%$ 정도라고 알려져 있다, ${ }^{2,17,18)}$. 본 연구에서는 2 명 $(9.1 \%)$ 에서 다른 문제가 동반되어 있었고, 1 예는 청색증으로 입 원 치료하던 중 생후 17 일에 왼쪽 반신비대와 큰 혀가 관찰되어 초 음파 검사를 하게 되었으며간 내부에 덩이가 발견되어 전원 된 경 우이다. 간모세포종이 진단되었으며 유전자검사까지 시행하여 H19 hypermethylation paternal uniparental disomy가 확인되었고 Beckwith-Widemann syndrome으로 최종 진단되었다. 다른 1 예는 반복된 복부 팽만이 있어 시행한 복부초음파에서 오른쪽 부신의 종 양이 확인된 경우로, 최종 기형종이 진단되었으며 수술 중 장 회전이 상이 발견되었으나 종양 발생과의 연관성은 명백하지 않았다. 전원 되었던 15 중 6명에 대해서는 의무기록지를 통해서는 Apgar score를 확인할 수 없었고 상세한 산모의 병력을 확인하는 것에 제한이 있었 다.

산전 이상을 발견하지 못하고 출생한 경우 중 산전 태아의 복수가 있었던 1예는 출생 당일 개복 수술하여 구불잘록창자에 발생한 종양
과 장 천공이 진단된 경우로 산전 초음파에서 종양은 보이지 않았고 장 천공으로 인한 복수만 확인된 것이었다. 1 예는 지속적인 복부 팽 만으로 생후 16 일째에 타 병원에서 초음파 시행 후 종양이 의심되어 전원이 되었으며 초음파와 자기공명영상검사로 오른쪽 부신의 종 양을 확인하고 수술 후 조직검사로 기형종을 진단하였다. 이 환자의 경우 반복된 복부 팽만은 종양 자체보다 동반된 장 회전 이상이 원인 으로 생각되었다. 앞서 기술한 생후 17 일에 왼쪽 반신비대와 큰 혀 가 인지되어 복부초음파를 시행하여 진단에 이르렀던 환자는 반복 적이고 주의 깊은 신체검사로 질병을 의심하는 것이 필요하다는 경 각심을 주는 경우로, 산전 진단이 나날이 개선되더라도 출생 후 신생 아를 돌보는 의사의 세심한 진찰은 필수적이라 하겠다.

병리조직검사 결과 양성 및 악성의 빈도가 각각 $63.6 \%, 36.4 \%$ 로 확인되었고 양성은 배아세포종양, 악성은 간모세포종이 가장 많았 는데 기존의 보고들에 의하면 대표적인 신생아기 고형종양은 배아 세포종양과 신경모세포종으로 알려져 있다 ${ }^{1,3-5)}$.

엉치꼬리 기형종은 가장 흔한 신생아기 종양으로 생존 출생아 40,000 명 중 1 명에서 발생하며 남녀 성비가 1:4로 여아에서 우세하 다고 알려져 있다 ${ }^{19}$. 산전 초음파에서 관찰되는 경우 고형 또는 고형 과 낭성의 혼재가 대부분이며 온전히 낭성인 경우는 드물다 ${ }^{20}$. 본 연 구에서도 7예가 엉치꼬리 기형종으로 전체 종양 중 가장 많은 빈도 를 보였고 5명이 여자로 알려진 바와 같이 여아에서 많았다.

간에 발생하는 종물은 신생아기 종물의 약 $5 \%$ 에서 관찰되는데, 혈관내피종, 중간엽 과오종, 간모세포종, 간세포샘종 등 다양한 양 성과 악성 종물이 발생할 수 있다 ${ }^{19)}$. 문헌에서는 혈관 관련 종양에 대해 혈관종, 영아 혈관종, 간의 동정맥 기형, 그리고 영아 혈관내피 종 등 다양하게 기술하고 있는데 ${ }^{21)}$, 혈관종이 간에 발생하는 가장 흔 한 양성종양이지만 생후 2 년 이내에 합병증 없이 자연 소실되는 빈 도가 높아 실제 발병율은 낮게 보고되는 것으로 알려져 있다 ${ }^{22,23)}$. 그 러나간 내 혈관종 파열로 인해 울혈성 심부전, 혈소판 감소증, 복강 내 출혈 등이 합병되는 경우에는 이로 인한 사망률이 $12-90 \%$ 로 다양 하게 보고 되고 있어 조직학적으로 양성이더라도 경과관찰 시 주의 가 필요하다 ${ }^{24}$. 간모세포종은 간에 발생하는 가장 흔한 악성 종양이 
지만 태아기부터 신생아기에는 혈관종이나 중간엽 과오종보다 적다 고 하였다 ${ }^{19)}$. 본 연구에서는 악성 2 예 모두 간모세포종으로 차이가 있었으나 한 기관에서 적은 환자수를 대상으로 한 연구이기에 비교 에 제한이 있다.

신경모세포종은 신생아에서 가장 흔한 악성종양으로 전체 악성 종양의 $20 \%$ 를 차지한다 ${ }^{25)}$. 태아기 및 신생아기에 발견되는 신경모 세포종은 $90 \%$ 이상에서 부신에 발생하며, 이후 소아 시기의 경우 단 지 $35 \%$ 에서 부신 발생인 것과 큰 차이가 있다 ${ }^{26,27)}$. 산전에 진단되는 경우 주로 임신 3분기에 진단되며 전형적으로 오른쪽 신장 위라고 알려져 있다 ${ }^{28)}$. 본 연구에서 2예는 임신 39주에 왼쪽 부신으로 발견 되었고, 1 예는 29 주에 오른쪽 부신에 위치한 것이 확인되었다. 큰 소 아나 성인의 경우와 달리 조직검사 상 악성이더라도 전반적인 예후 는 아주 양호한 특성이 있는데, 이는 1 세 미만의 영아에서 발생한 경 우 자연퇴화가 가능하기 때문이다 ${ }^{29)}$. 이러한 이유로 본원에서 치료 한 환자들도 보조항암치료 없이 추적 중이다.

전반적인 경과는 신생아기 이후의 소아 종양과는 다른 차이를 보 이며, 일부에서는 신생아기 종양이 급속히 진행되어 훨씬 더 나쁜 예 후를 보인다고 하였다 ${ }^{30-32)}$. 고형 종양의 해부학적 위치나 크기에 따 라 수술적 처치를 시행해야 하는 경우 큰 소아나 성인에 비해 수술 전후 신체 대사 항상성유지에 어려움이 발생할 수 있어 주의를 요한 다. 본 연구의 모든 예에서 수술 전-후 원격전이는 발견되지 않은 국 소 질환으로 확인되었는데, 이는 신생아기 종양의 특성 상 병리조직 학적으로 악성 소견을 보이더라도 임상 양상이 항상 일치하지 않는 특성을 반영한다고 할 수 있다. 그리고 신생아기 종양 적출 수술 후 보조항암치료를 시행한 3예도 추적 기간 중 재발이나 사망은 없었 다. 신생아기 종양 자체의 드문 빈도를 감안할 때 본 연구의 결과로 신생아 종양은 다른 시기 소아종양에 비해 더 나쁜 예후를 보이지 않 는 것으로 생각되나 향후 더 많은 증례에 대한 경과 관찰이 필요하겠 다.

신생아기에 발견되는 복부 및 회음부 고형종양의 경우 임상적으 로 4가지 측면을 주의하여 치료해 나가야 한다. 첫째, 출생 전후기 측면에서 종양 자체가 태아에 영향을 미칠 수 있다는 것과 양성-악 성에 대한 감별이 어렵다는 것으로, 이에 대한 치료는 출생 전-후 발 현되는 증상과 연관이 많다. 따라서 처치에 있어 가능한 경우 외과 적 완전 절제를 바탕으로 여러 전문분야적 접근이 이루어져야 하며, 신생아집중치료실에 입원 중 발현될 수 있는 연관 징후와 증상 확인 및 향후 처치에 있어 신생아 의료진의 역할이 매우 중요하겠다. 둘 째, 분만 방식과 분만 후 신생아의 치료에 대한 고려가 필요하다. 즉 크기가 매우 큰 종양의 경우 자연질식분만 진행이 어려울 수 있으므 로 안전한 분만 방식에 대한 선택이 필수적이며, 분만 후 즉각적인 치료가 필요할 것으로 예견되는 경우에는 산모를 전문적인 신생아 집중치료가 가능한 의료기관으로 이송하여 분만하도록 해야 한다. 셋째, 신생아 악성 종양에 대한 수술 후 보조화학요법에 대한 측면이
다. 신생아기는 아직 신장 및 간 기능의 미성숙하며, 항암제로 인한 세포독성과 약동학적 자료가 부족한 실정으로 투여 용량 조절 및 약 물 농도 감시에 대한 어려움이 있어 주의를 요한다 ${ }^{33)}$. 마지막으로 신 생아 보호자에 대한 심리적 지지도 함께 이루어져야 한다. 신생아기 에 종양을 진단받고 수술 및 약물치료가 시행되어야 하는 상황에 대 한 보호자의 심리적 고통에 대해 이해하고 뒷받침하는 것은 원활한 치료종결뿐만 아니라 퇴원 후 가정에서 관리 및 추적에도 큰 영향을 준다. 이 점에서도 여러 관련 전문분야의 협력 진료가 도움이 되겠 다.

본 연구는 국한된 지역에서 수집된 표본으로 인해 정확한 발생빈 도를 예측하기 힘들다는 것과 후향적 연구로 산모와 산전 진단에 대 한 정보가 부족하다는 제한이 있다. 그러나 신생아기 종양 자체가 드문 점을 고려해 볼 때, 어느 정도 유의한 자료를 제시할 수 있다고 생각된다.

결론적으로, 신생아기 복부-회음부 고형종양은 산전관리 확인부 터 출생 후 진단까지 다양한 소견을 보일 수 있으며, 양성종양은 배 아세포종양 악성종양은 간모세포종이 많았다. 최종 진단 질환에 따 라 적합한 치료와 경과가 다르겠지만 산전-후에 여러 전문분야의 협 력 진료를 적극적으로 한다면 수술 후 경과에 있어 비교적 좋은 예후 를 기대할 수 있으리라 생각된다.

\section{REFERENCES}

1) Moore SW, Satgé $D$, Sasco AJ, Zimmermann A, Plaschkes J. The epidemiology of neonatal tumours. Report of an international working group. Pediatr Surg Int 2003;19:509-19.

2) Halperin EC. Neonatal neoplasms. Int J Radiat Oncol Biol Phys 2000;47:171-8.

3) Orbach D, Sarnacki S, Brisse HJ, Gauthier-Villars M, Jarreau PH, Tsatsaris V, et al. Neonatal cancer. Lancet Oncol 2013;14:e60920.

4) Vormoor J, Chintagumpala M. Leukaemia \& cancer in neonates. Semin Fetal Neonatal Med 2012;17:183-4.

5) Lee TC, Olutoye OO. Evaluation of the prenatally diagnosed mass. Semin Fetal Neonatal Med 2012;17:185-91.

6) Parkes SE, Muir KR, Southern L, Cameron AH, Darbyshire PJ, Stevens MC. Neonatal tumours: a thirty-year population-based study. Med Pediatr Oncol 1994;22:309-17.

7) Willis RA. The embryonic tumours and teratomas. In: Willis RA. The borderland of embryology and pathology. 2nd ed. London : Butterworths, 1962:422-66.

8) Spector LG, Puumala SE, Carozza SE, Chow EJ, Fox EE, Horel S, et al. Cancer risk among children with very low birth weights. Pediatrics 2009;124:96-104. 
9) Desandes E, Guissou S, Ducassou S, Lacour B. Neonatal solid tumors: incidence and survival in France. Pediatr Blood Cancer 2016;63:1375-80.

10) Gurney JG, Severson RK, Davis S, Robison LL. Incidence of cancer in children in the United States: sex-race-and 1-year agespecific rates by histological type. Cancer 1995;75:2186-95.

11) Lichtenstein P, Holm NV, Verkasalo PK, Iliadou A, Kaprio J, Koskenvuo M, et al. Environmental and heritable factors in the causation of cancer--analyses of cohorts of twins from Sweden, Denmark and Finland. N Eng J Med 2000;343:78-85.

12) Doll R, Wakeford R. Risk of childhood cancer from fetal irradiation. Br J Radiol 1997;70:130-9.

13) Potter EL. A historical view: diethylstilbestrol use during pregnancy: a 30-year historical perspective. Pediatr Pathol 1991;11: 781-9.

14) Bruisma F, Venn A, Lancaster P, Speirs A, Healy D. Incidence of cancer in children born after in-vitro fertilization. Hum Reprod 2000;15:604-7.

15) Buckley JD. The aetiology of cancer in the very young. Br J Cancer Suppl 1992;18:S8-12.

16) Schüz J, Kaatsch P, Kaletsch U, Meinert R, Michaelis J. Association of childhood cancer with factors related to pregnancy and birth. Int J Epidemiol 1999;28:631-9.

17) Altmann AE, Halliday JL, Giles GG. Associations between congenital malformations and childhood cancer: a registerbased case-control study. Br J Cancer 1998;78:1244-9.

18) Moore SW. Neonatal tumours. Pediatr Surg Int 2013;29:1217-29.

19) Isaacs H, Jr. Tumors of the fetus and newborn. Major Probl Pathol 1997;38:224-97.

20) Tongsong T, Wanapirak C, Piyamongkol W, Sudasana J. Prenatal sonographic features of sacrococcygeal teratoma. Int J Gynaecol Obstet 1999;67:95-101.

21) Woodward PJ, Sohaey R, Kennedy A, Koeller KK. From the archives of the AFIP: a comprehensive review of fetal tumors with pathologic correlation. Radiographics 2005;25:215-42.
22) Dreyfus M, Baldauf JJ, Dadoun K, Becmeur F, Berrut F, Ritter J. Prenatal diagnosis of hepatic hemangioma. Fetal Diagn Ther 1996;11:57-60.

23) Chuileannain FN, Rowlands S, Sampson A. Ultrasonographic appearances of fetal hepatic hemangioma. J Ultrasound Med 1999;18:379-81.

24) Fishman SJ, Mulliken JB. Hemangiomas and vascular malformations of infancy and childhood. Pediatr Clin North Am 1993; 40:1177-200.

25) Bader JL, Miller RW. US cancer incidence and mortality in the first year of life. Am J Dis Child 1979;133:157-9.

26) Acharya S, Jayabose S, Kogan SJ, Tugal O, Beneck D, Leslie D, et al. Prenatally diagnosed neuroblastoma. Cancer 1997;80:30410.

27) Lonergan GJ, Schwab CM, Suarez ES, Carlson CL. Neuroblastoma, ganglioneuroblastoma, and ganglioneuroma: radiologic-pathologic correlation. Radiographics 2002;22:911-34.

28) Houlihan C, Jampolsky M, Shilad A, Prinicipe D. Prenatal diagnosis of neuroblastoma with sonography and magnetic resonance imaging. Ultrasound Med 2004;23:547-50.

29) Granata C, Fagnani AM, Gambini C, Boglino C, Bagnulo S, Cecchetto $\mathrm{G}$, et al. Features and outcome of neuroblastoma detected before birth. J Pediatr Surg 2000;35:88-91.

30) Batcup G. Cancer in the very young child--pitfalls and problems for the pathologist. Br J Cancer Suppl 1992;18:S5-7.

31) Moore SW, Kaschula ROC, Albertyn R, Rode H, Millar AJW, Karabus $\mathrm{C}$. The outcome of solid tumours occurring in the neonatal period. Pediatr Surg Int 1995;10:366-70.

32) Rao S, Azmy A, Carachi R. Neonatal tumours: a single-centre experience. Pediatr Surg Int 2002;18:306-9.

33) Kearns GL, Abdel-Rahman SM, Alander SW, Blowey DL, Leeder JS, Kauffman RE. Developmental pharmacology--drug disposition, action, and therapy in infants and children. N Engl J Med 2003;349:1157-67. 